\title{
Do espelho machadiano ao ciberespelho: interioridade na atual cultura somática*
}

\section{RESUMO}

Na cultura contemporânea, observa-se o esvaziamento do regime moderno da interioridade, vinculado ao conflito entre a profundidade psicológica e a superfície das máscaras sociais. Declina o homem psicológico, em favor de novos roteiros de subjetivação, não mais balizados pela tensão dialética entre dentro/fora, interior/ exterior. A “interioridade" se reconfigura, em consonância com a dominação cultural crescente das neurociências e da cultura somática, que privilegia a esfera bioquímica e molecular do corpo (cérebro, hormônios e genes).

\section{PALAVRAS-CHAVE}

subjetividade contemporânea

regimes de interioridade

cultura somática

\section{ABSTRACT \\ In contemporary culture there seems to be a progressive decli- ne of the modern interiority, based on the conflict between a psychological deepness and the surface of social masks. Nowa- days a certain decline of the psychologically configurated subjectivity can be observed, as well as a gradual rise of new scripts of subjectivation which are no longer organized in terms of a tension between two poles: inside/outside, interiori- ty versus exteriority. "Interiority" tends to be reconfigured, following the increasing cultural domination of neurosciences and the emergence of the somatic culture, which stresses the biochemical and molecular levels of the bodies (specially brain, hormones and genes).}

\section{KEY WORDS}

contemporary subjectivity

regimes of interiority

somatic culture
Tendo percorrido com expressivo sucesso de público mais de 30 cidades do mundo, a exposição "Corpo Humano Real e Fascinante", apresentada até fevereiro de 2009 no Museu Histórico Nacional do Rio de Janeiro, foi divulgada em jornais com uma significativa chamada publicitária: "Você tem um encontro marcado com o seu interior". Nesse slogan, ressoa obviamente (ao menos para certa geração letrada) o título de uma conhecida obra do escritor mineiro Fernando Sabino, que marcou época ${ }^{1}$. Mas essa memória é colocada a serviço de uma nova perspectiva acerca do que seria um encontro consigo mesmo e, sobretudo, do que consistiria o "interior". A esse slogan soma-se, por exemplo, este outro: "Descubra como você é por dentro". Ou ainda: "Venha ver do que você é feito".

Trata-se de uma exposição em que corpos reais (reais e fascinantes: outro significativo mote da exposição), de cadáveres chineses plastificados, revelam seu verdadeiro interior, ou seja, o que se é verdadeiramente por dentro: órgãos, vísceras, veias, ossos, músculos, mas também próteses - caucionando a rasura da velha dicotomia natural/artificial. O corpo morto é fragmentado, purificado tanto de seus odores, de sua temporalidade orgânica e de sua irrefreável tendência natural à putrefação, quanto de qualquer história ou ancoragem político-social. Expõe-se, em certa seção, horizontalmente fatiado, em camadas, emulando imagens digitais que ressonâncias magnéticas ou tomografias computadorizadas podem fornecer. Ressecado, desencarnado e digitalizado, esse corpo humano serve como suporte didático tanto para a vulgarização científica quanto para a incitação a um "cuidado de si" centrado em hábitos saudáveis de vida. Por exemplo, após ver pulmões destruídos pelo tabaco, o visitante é convidado a depositar em uma urna de acrílico transparente (em geral repleta) seu inimigo, verdadeiro atentado contra as boas normas da saúde e da prevenção de riscos. Eis uma das óbvias faces da intensa moralização que tem recoberto de modo cada vez mais evidente as práticas somáticas.

Como inúmeros produtos culturais e midiáticos que permeiam nosso cotidiano, essa exposição exprime a tendência atual de ultrapassagem do regime moderno da interioridade, em favor de uma ênfase crescente no âmbito somático, na bioquímica do corpo, acompanhada por um processo de externalização do eu na superfície lisa de imagens, especialmente de neuroimagens. No limiar de 2009, abre-se outra exposição internacional, dessa vez na Casa de Ciência da UFRJ, intitulada: "Paisagens neuronais". Nela são expostas "imagens inéditas" (digitais, leves e multicores) do sistema nervoso elemento privilegiado na cultura somática, em plena

\section{Maria Cristina Franco Ferraz}

Professora do Programa de Pós-graduação em Comunicação da UFF/R/BR mcfferraz@hotmail.com 
sintonia com os corpos superexcitados e hiperexcitáveis contemporâneos. Conforme chamada na revista Zona Sul, do jornal "O Globo" de primeiro de janeiro de 2009, o diretor do Instituto ressalta que "a variedade das formas e dos efeitos luminosos surpreende o espectador". De fato, a se julgar pela imagem ilustrativa da chamada, as cores ressaltam na imagem sobre um fundo negro, lembrando o efeito bem conhecido e divertido da luz negra.

Nessa exposição, o personagem principal é o cérebro, com suas redes neurais, mostradas nas figuras abstratas e multicores reveladas por tecnologias digitais. Ela presta homenagem ao cientista espanhol Santiago Ramón y Cajal, precursor das atuais neurociências, bem como da reprodução visual do cérebro, dos diagramas em rede da composição neuronal. Na virada do século XIX para o XX, Ramón y Cajal desenhou com esmero redes neurais diversas. A exposição privilegia neuroimagens atuais, acompanhadas de frases e de pequenos textos produzidos por escritores, intelectuais, pintores, filósofos e escultores. Referências pictóricas - Mirò, por exemplo - e literárias acoplam-se a "fotos" de neurônios (em geral, não humanos), submetendo-se por vezes ironicamente ao fascínio e à persuasão exercidos por imagens neurais. A ironia é dirigida à tradição literária e pictórica moderna, não às atuais crenças que subjazem às neuroimagens. Uma das imagens, por exemplo, é interpretada sinteticamente como: "Godot chegou?". Emoções, sentimentos (como a ira) e micro narrativas também comparecem nessa leitura interpretativa e "artística" de neuroimagens. Ou seja: o vocabulário dos afetos, protocolos narrativos, a tradição literária e pictórica ocidental se rendem às neuroimagens, a pontando para a relevância de explicações cerebralistas e fisicalistas de todos os fenômenos humanos, do próprio mistério da "personalidade", conforme o vídeo sobre o funcionamento do cérebro que abre a exposição.

$\mathrm{O}$ "interior" do corpo, exteriorizado no fascínio luminescente e multicor das neuroimagens, torna-se assim paisagem neuronal, inserindo-se mais sutilmente em uma larga tradição pictórica ocidental para alterá-la profundamente, uma vez que um gesto inédito de "paisagismo" passa a se impor. À ênfase na rede de neurônios em que o corpo se resume associa-se, portanto, uma nova visão da interioridade, rebatida sobre um tipo de imagem em que têm se apoiado as neurociências em expansão, espraiando-se e consolidando sua credibilidade na cultura contemporânea. Cabe lembrar que o avanço das neurociências tem se valido, em geral, do amplo desenvolvimento de novas tecnologias de imageamento corporal, sobretudo cerebral, o que salienta, no livro de divulgação científica Memória, o neurocientista radicado no Brasil Iván Izquierdo:

Um passo adiante na determinação das áreas envolvidas nas memórias foi dado pelas modernas técnicas de imagens, das quais a mais usada hoje é a ressonância magnética nuclear. Essas técnicas medem indiretamente a ativação metabólica de uma ou outra região do cérebro... (Izquierdo, 2002, p. 41).

Nesse contexto, o que na modernidade era mais "interior" - a velha vida subjetiva, com seus conflitos, dilemas e aventuras - desloca-se para a materialidade somática, atravessada por saberes científicos em franco desenvolvimento e por um regime de visibilidade digitalizante. Aquilo que somos mais autenticamente passa a referir-se a um corpo fragmentado, cientificamente esquartejado, alcançando-se sua composição molecular. Tal concepção tem privilegiado, em especial, os seguintes vetores: o cérebro, hormônios (moduladores da atividade neuronal) e os genes. Indicativo da expansão cultural desses saberes, um vocabulário bioquímico, hormonal, invade significativamente a linguagem cotidiana: à excitação que certo tipo de cinema produz, é diretamente associada à liberação de adrenalina (adjetivando-se, inclusive, na expressão "cinema-adrenalina"); ao prazer e à sensação de bem-estar, ligados, por exemplo, às práticas de fitness, a liberação de endorfina; à tristeza, ressignificada como "depressão", níveis e taxas de serotonina; à atenção cada vez mais requerida e, ao mesmo tempo, levada a dispersar-se entre excitações concorrentes, a ritalina.

Vai-se assim consolidando o que alguns autores chamam, apropriadamente, de cultura somática, na qual declina o modo de subjetivação moderno, ancorado na experiência de si como sujeito dotado de interioridade, em favor de biossociabilidades (Rabinow, 1999), bioidentidades (Freire Costa, 2005), individualidades somáticas ou mesmo selves neuroquímicos (Rose, 2007). Desde o início dos anos 90, o antropólogo norte-americano Paul Rabinow ressaltou, pioneiramente, de que modo o projeto Genoma sinalizava essa ênfase no biológico, em suas implicações identitárias. O conceito de biossociabilidade, desdobramento e atualização do biopoder foucaultiano (Foucault, 1976), enfatiza a formação de novas identidades, de novas práticas individuais e grupais no âmbito do capitalismo atual:

Haverá grupos portadores de neurofibromatose que irão se encontrar para partilhar experiências, fazer lobby em torno de questões ligadas a suas doenças, educar seus filhos, refazer seus ambientes familiares, etc. É isto o que entendo por biossociabilidade. Nós não estamos falando de algum gene hipotético responsável pela agressão ou pelo altruísmo. Haverá, sim, grupos formados em torno do cromossomo 17 , locus 16.256 , sítio 654.376 , alelo com substituição de uma guanina. Esses grupos terão especialistas médicos, laboratórios, histórias, tradições e uma forte intervenção dos agentes protetores para ajudá-los a experimentar, partilhar, intervir e "entender" seu destino.

E será mesmo destino. Ele não será portador de 
nenhuma profundidade. (Rabinow, 1999, p. 147).

No século XXI, esses grupos já se encontram amplamente organizados em sites e blogs na Web. O pioneirismo coube aos portadores de AIDS, mas a biossociabilidade estende-se, atualmente, a outras síndromes, tais como as de Huntington (Rose, 2007, p. 93) ou de Asperger (Montardo e Passerino, 2008). No contexto da cultura somática, assiste-se assim a um esvaziamento do regime da interioridade psicológica, vinculado ao modo moderno de se subjetivar. A interioridade passa paulatinamente a reconfigurar-se, nas práticas e valores que impregnam os roteiros de subjetivação contemporâneos. Não se trata, evidentemente, da substituição de um modo por outro, como por vezes a ênfase (e a retórica) teorizante pode levar a sugerir. O que ocorre é, antes, uma mutação mais ou menos perceptível nas inflexões e rearranjos do regime (e do vocabulário) das práticas subjetivantes. $\mathrm{Ou}$, mais precisamente, uma subordinação de antigos mecanismos por outros emergentes, que vão se consolidando. Nesse sentido, o slogan da exposição "Corpo humano", inicialmente comentado ("Você tem um encontro marcado com o seu interior"), torna-se, mais uma vez, bastante revelador.

Para dimensionar de modo mais preciso essa mudança, é necessário lembrar como se constituiu a subjetividade moderna. Uma das vias mais instigantes encontrase indicada nas perspectivas teóricas de dois pensadores seminais, em textos do final dos anos 70: Michel Foucault e Richard Sennett. Na parte de sua obra dedicada à analítica das relações de poder-saber, Foucault enfatizou a produção da subjetividade escavada nas profundezas da interioridade psicológica balizada pelo desejo, articulando a sexualidade como dispositivo à fundação das ciências humanas e do próprio campo psi (Foucault, 1976). Coetaneamente, Richard Sennett privilegiou as implicações da emergência e da valorização moderna da "intimidade" (Sennett, 1999), ressaltando a dialética entre o público e o privado. Segundo Sennett, à diferença do theatrum mundi do século XVIII, nas metrópoles européias modernas em expansão (Paris e Londres), a cena pública passou a ser vivida como um ardiloso campo de máscaras enganosas, enquanto o âmbito privado ia-se progressivamente confundindo com a esfera da autenticidade e da produção da "verdadeira" identidade. Essas perspectivas teóricas permanecem fundamentais. Mas há igualmente outro caminho promissor para retomarmos a problemática da subjetividade moderna, um viés ainda mais direto (e talvez mais saboroso) que permite igualmente a exploração dos meandros do regime moderno da interioridade: a referência à literatura moderna.

A subjetividade moderna, interiorizada, psicologicamente tramada, desenvolveu-se em campos paralelos, historicamente adjacentes, nem sempre totalmente simultâneos. Ela teve na literatura, a partir do final do século XVII e, sobretudo, da virada do século XVIII para o XIX, um locus privilegiado de exercício e de elaboração, bem antes de alcançar consistência e estatuto epistemológico nas ciências psicológicas do final do século XIX. $\mathrm{Na}$ literatura francesa, por exemplo, foi escavada em textos ficcionais precursores dos romances psicológicos, como La princesse de Clèves, de Madame de Lafayette (1678), e Adolphe, de Benjamin Constant (1816). Nesse último, inaugura-se uma nova investigação dos "movimentos do coração", que irão se tornar o objeto central do movimento romântico de volta sobre si mesmo, em um gesto de introspecção psicológica. A própria psicanálise, com Freud, irá se valer de uma ampla tradição literária antecedente, em que se elaborou e fixou o homem psicológico moderno (Bezerra, 2002, p. 230), balizado pelo conflito, pelas tensões e embates entre a esfera profunda do desejo e as exigências do mundo social. Sua versão epistemológica é mais tardia, remetendo à passagem do século XIX ao XX, com a expansão do conceito de desejo, articulado ao de sexualidade (Foucault, 1976), que passará cada vez mais a identificar e a especificar o que se é verdadeiramente.

No final do século XIX e limiar do XX, também encontramos na literatura brasileira um expressivo desdobramento da problemática referente a esse modo de se subjetivar. As recentes homenagens a Machado de Assis convidam a uma releitura de alguns de seus textos e, no caso que nos interessa aqui, em especial de um conto em que a dialética moderna interior/exterior se expressa com sagacidade e agudeza. Trata-se do conto "O Espelho" publicado no livro Papéis avulsos (1882). O subtítulo é, por si só, bastante instigante, indicando o que ele propõe e tematiza: nada menos do que o "esboço de uma nova teoria da alma humana". Como se vê, o que está em jogo é, para começar, a alma, não o corpo - ainda que, como mostrou Nietzsche, a alma seja sempre efeito de práticas históricas sobre o corpo. O conto se organiza como ilustração de uma tese sustentada por um personagem (Jacobina), apoiada em uma breve fábula autobiográfica. A nova teoria pode ser assim resumida: teríamos de fato não uma, mas duas almas, "uma que olha de dentro para fora, outra que olha de fora para dentro".

Retomemos brevemente a teoria das duas almas para verificar, a seguir, em que medida ela se encontra esvaziada e deslocada na cultura contemporânea, mantendo presente a questão que nos move: a reconfiguração da interioridade na cultura somática. Em síntese, e aproveitando a metáfora machadiana (metáfora, aliás, tradicionalmente privilegiada para o desenvolvimento tanto da mimesis quanto da formação identitária): nos novos espelhos digitais, virtuais, seria ainda possível se encontrar a mesma tensão entre as duas almas formulada no conto machadiano? Ou um franco declínio de toda alma? Vamos primeiro ao conto. Em meio a discussões "de alta transcendência", em uma casa situada em Santa Teresa - suspensa entre o alvoroço da cidade e um céu machadianamente alheio e sereno -, Jacobina, homem de meia idade, toma por fim a palavra. Para apoiar sua tese 
acerca das duas almas - uma interior, outra exterior -, Jacobina narra certa passagem de sua juventude.

Eis, em síntese, o episódio que sustenta a tese da duplicidade de almas. Aos vinte e cinco anos, Jacobina, rapaz pobre, é nomeado alferes da guarda nacional. A partir de então, passa a suscitar, à sua volta, tanto admiração quanto despeito e inveja. A farda lhe é ofertada por amigos. Sua tia Marcolina, que morava em um sítio fora da cidade, deseja vê-lo e festejá-lo, agora fardado e alferes. Jacobina parte então para o sítio, onde vai aos poucos deixando de ser chamado, como antes, de "Joãozinho", passando a ser tratado todo o tempo como "senhor alferes". As deferências que lhe são reservadas culminam com a mudança de um belo e rico espelho da sala para o quarto do Alferes Jacobina. Esse prestigioso espelho, segundo a lenda familiar (e a ironia machadiana), fora comprado a uma das fidalgas da comitiva de Dom João VI, em 1808. Como se pode desde já observar, o espelho da ficção identitária e mimética aponta para si mesmo nessa anedota: concretiza-se e materializa-se, inserindo-se centralmente no enredo para ilustrar a nova tese apresentada.

Jacobina ressalta que o acúmulo de obséquios, carinhos e atenções de que era cercado no sítio da tia terminaram por resultar em uma grande transformação, lapidarmente expressa pelo próprio personagem-narrador: "o alferes eliminou o homem". Jacobina transforma-se, por fim, em sua imagem refletida tanto no luxuoso espelho quanto no olhar deferente e admirativo dos outros. Observe-se que sua transformação em imagem e reflexo é experimentada e teorizada como anulação do "homem", este confundindo-se com a autenticidade aninhada no interior - na alma, até então unívoca, interior. É essa alma verdadeira que vai naufragando no afã pelo reconhecimento social. Vai que certo dia a tia precisa fazer uma viagem para acudir uma filha doente, deixando o Alferes tomando conta da propriedade. Os dias se passam sem que retornem os parentes. Os escravos da propriedade substituem, entretanto, a função especular, mantendo ativada a "alma exterior" de "Nhô alferes", arranhada pela ausência do espelho doméstico, socialmente qualificado. Entretanto, as mesuras dos escravos terminam-se revelando como pura astúcia: certa noite, todos fogem, e Jacobina encontra-se por fim só na propriedade.

Ocorre então que, sem o reflexo dos olhares e das deferências, sua alma exterior, a que se reduzira tudo o que era, se perde também ela radicalmente. Jacobina defronta-se então com a noite, o abismo e o nada, interrompidos apenas por sonhos em que retornam a farda, o reconhecimento da família e dos amigos - em que volta, em suma, como assombração e espectro, o Alferes. De dia, entretanto, o espelho vetusto nada mais refletia senão "uma nuvem de linhas soltas, informes". Ou seja: a alma exterior, em que Jacobina se desdobrara e resumira, não emergia nem retornava, deixando-o à deriva. É nesse momento que o personagem lança mão de um curioso estratagema: veste todo dia a farda de alferes, põe-se frente ao espelho, recuperando dessa forma sua "figura integral", aquela alma exterior em que se tornara e que lhe escapara na solidão total do sítio. A partir de então, decide vestir a farda todo dia a certa hora, gesticulando, sorrindo e perambulando frente ao grande espelho. Por meio desse expediente, resgata sua imagem e inteireza, deixa de ser um autômato e volta a ser um "ente animado".

Essa deliciosa fábula machadiana explora tensões presentes na constituição da identidade moderna: dentro e fora, alma interior e alma exterior, ser e parecer. $\mathrm{O}$ jogo entre a mera imagem social e uma suposta verdade íntima: eis o que o conto de Machado põe evidentemente em xeque. O homem moderno experiência tanto a necessidade de sustentar-se identitariamente em sua "interioridade" quanto às pressões dos papéis a serem cumpridos no teatro social. A questão é que as máscaras colocadas, como bem o sabiam Nietzsche e Machado, dificilmente podem ser retiradas, fundindo-se e confundindo-se com o rosto que pareciam preservar. Esse jogo entre interioridade, privacidade autêntica e falsidade da vida e das máscaras sociais marca, como apontou Sennett (Sennett, 1999), os dilemas da identidade moderna. A subjetividade moderna cinde-se, desdobra-se na melhor das hipóteses em um dentro e em um fora: o primeiro, guardião do que efetivamente se é; o segundo, reino do engano, do cálculo e da mentira. Entretanto, como observa Machado de Assis, esse suposto "interior" é necessariamente produzido nas relações com o espelho do mundo compartilhado, pelo jogo social. A tese sustentada por Jacobina termina por corroer tal "intimidade" mais verdadeira, revelando-a, também a ela, como tributária do olhar especular do outro.

Entretanto, ainda que essa "alma interior" seja mostrada como produção social e histórica, a teoria defendida por Jacobina se apresenta como uma "nova teoria da alma". Inscreve-se, portanto, em uma longa tradição filosófica e literária, com a qual mantém um diálogo crítico (e paródico): tanto com relação a crenças metafísicas arraigadas no Ocidente - sobretudo o jogo socráticoplatônico entre essência (verdadeira) e aparência (reino do falso), rebatidas sobre a dialética moderna privado/ público - quanto com teorias e novos campos epistemológicos desenvolvidos no final do século XIX. Trata-se ainda de alma - em grego, psyche -, mesmo em sua versão cindida e duplicada, com sua pretensa coerência e unidade corroída pelos sardônicos vermes da suspeição, pela crise moderna da crença em valores eternos e em essências imutáveis. As tensões que dissolvem a pretensão a uma unidade essencializante (a velha alma), se a duplicam, não a destroem de todo. Prova disso, ainda no âmbito do enredo, é que a tese apresentada e ilustrada por Jacobina surpreende os ouvintes (conforme o texto, "investigadores de cousas metafísicas" [Machado, 1974, p. 345]), deixando-os no final boquiabertos, pasmos e perplexos. 
Ora, na cultura contemporânea é a própria tensão interior/exterior e o tradicional privilégio concedido à alma (mesmo sob a forma de uma alma partida) que parecem ter perdido sua vigência e eficácia. Na cultura somática, do espetáculo e da imagem, essa tensão interior/exterior tende a se esfacelar, esvaziando, no mesmo gesto, a dialética público/privado. Perfis identitários associam-se de modo cada vez mais explícito à lógica do consumo e espetacularizam-se na superfície dos corpos. Esse novo modo de se subjetivar deixa de convocar o dilema moderno ser/parecer, referência fundamental no conto machadiano. Como acentuou, desde 1967, Guy Debord (Debord, 1992), na sociedade do espetáculo, na qual as relações consigo e com o outro são em geral mediadas por imagens, ser confunde-se cada vez mais com ser visto. O espelho machadiano se estilhaça, dando lugar a espelhos midiáticos, bem como a neuro- e ciberespelhos. No lugar de duas almas, do conflito entre a interioridade e o jogo de máscaras sociais, trata-se de um mundo de reflexos especulares e espetaculares.

De modo coerente, o próprio lema da TV Globo se enuncia como espelho em que "a gente se vê por aí", remetendo evidentemente pelo menos a dois sentidos complementares: um reflexivo (nos vemos e reconhecemos), outro remetido à sociabilidade (nos encontramos). Na contemporaneidade, por conta de processos históricos em curso, vai-se dissolvendo a crença na velha "alma interior". Com ela, declina também, necessariamente, a "alma exterior", aquela produzida pelas fardas do reconhecimento social. A própria exteriorização da alma funcionou como vimos no espelho machadiano, como mais uma das estocadas mortais disferidas em direção à velha crença na unidade indivisível da alma. No mesmo movimento, parece também ter-se quebrado o espelho do outro. Restam talvez tão-somente superfícies deslizantes, sem alma - termo tornado tão obsoleto quanto obscuro -, em que nos refletimos não mais como seres em conflito consigo e com o teatro do mundo. Ou ainda o interior da materialidade do corpo, espetacularizado e exteriorizado em novas paisagens imagéticas. Trata-se, portanto, de um interior de outra ordem, percebido e vivido como paisagem, como superfície de inscrição imagética. Pois, como antecipou Nietzsche, não se destrói o "mundo verdadeiro" sem se eliminar, de fato e no mesmo gesto, o antigo "mundo aparente" (Nietzsche, 2000, p. 32). O que está em jogo não é uma mera inversão, um virar pelo avesso o interior, identificando-o à exterioridade das superfícies corporais; trata-se, antes, do colapso do próprio par opositivo interior/exterior. No mesmo movimento, emergem novas versões e sentidos para a interioridade, perspectivas que vamos literalmente incorporando, paisagens que somos levados a habitar, mesmo (e sobretudo) de modo inadvertido e cotidiano.

Para verificarmos essa problemática, vale a pena nos determos brevemente em certos fenômenos e produtos culturais contemporâneos. Vejamos, por exemplo, um vídeo do YouTube, que foi destacado em um trabalho apresentado no encontro da Compós de 2008, no GT "Comunicação e cibercultura" 2 . Trata-se do vídeo, que circula há dois anos na Web, já bastante visitado, e que se intitula "How do u get that lonely"3. Sozinha em seu quarto, diante da tela do computador e da webcam - que ajeita de início, alcançando-nos de relance com o olhar, uma adolescente desglamurizada cantarola melancolicamente uma conhecida canção americana country que fala de solidão e vazio. Isolada em um quarto, a menina grava essa cena comum aparentemente distraída, amarrando o tênis enquanto repete o refrão: "How do u get that lonely? How do you feel so empty?". Em primeiro lugar, cabe ressaltar a estética cuidadosamente descuidada, que empresta autenticidade e familiaridade a esse modo de tratar a imagem, emulando o caráter provisório e espontâneo próprio aos filmes digitais caseiros. Eis alguns traços dessa estética da intimidade flagrada em seu cotidiano trivial: precariedade e achatamento das imagens e dos personagens, enquadramentos oblíquos e não totalizantes, ausência de edição, bem como um jogo de olhares enviesados, que em geral evitam dirigir-se para a câmera.

Alguns desses cacoetes e protocolos estilísticos são por vezes retomados na própria produção cinematográfica atual, quando ela procura imitar vídeos privados. Paradoxalmente, a obviedade e a repetição desses recursos podem suscitar exatamente o oposto do efeito pretendido: a percepção do descuido como estratégia para produzir um ar de familiaridade e de autenticidade. $\mathrm{O}$ vídeo "How do u get that lonely" nem mostra uma "alma interior" se auto-perscrutando nem indica uma tentativa de recuperar qualquer "alma exterior perdida". Nesse modo de se subjetivar, o olhar especular do outro é convocado de maneira intrinsecamente mediada. A tensão entre uma alma "que olha de dentro para fora" e outra que "olha de fora para dentro", enfatizada no conto machadiano, vem se substituir um novo jogo de olhares que tem como elemento constituinte seu caráter mediado. O meio, a mediação, linhas de fratura e ruína do jogo dialético, ganham centralidade, inviabilizando relações dicotômicas espacializantes (dentro/ fora; interior/exterior). Como nos olhares por tabela freqüentes no espaço público de grandes cidades, os reflexos nas janelas (de metrôs, de transportes urbanos em geral) permitem trocas em meios mais hostis e perigosos.

O lance de olhar tramado pelo vídeo pode ser, assim, uma pista interessante a ser seguida, em cotejo com a dupla direção apontada na teoria das duas almas de "O espelho". No conto, às duas almas correspondia um olhar duplo, em mão e contramão: "uma que olha de dentro para fora, outra que olha de fora para dentro". Mas de onde olha a menina do vídeo? E para onde? Expõe-se, distraída, ao olhar alheio e errante do visitante do site, provavelmente também ele (ou ela) isolado em outro local fechado. Não há nem um dentro nem um fora que possam servir de referência, mesmo que para um tenso e desconcertante embate. Resta o cruzamento alea- 
tório de olhares ocultos e distantes, corroborando os sentimentos mecanicamente repetidos, sem qualquer pathos dramático, expressos na canção cantarolada: solidão e vazio.

Em "How do u get that lonely", enquanto a adolescente de rosto espinhento enquadra em diagonal sua "intimidade", cantarola baixinho e desafinadamente trechos da canção em que solidão e vazio se repetem. Entretanto, por duas vezes ela lança seu olhar de relance para a câmera e para os prováveis solitários do lado de lá (ou de cá). Esse procedimento ardiloso tem por efeito restituir a possibilidade da expressão e da comunicação de um estado que dificilmente se poderia chamar de estado de "alma". Não se trata evidentemente, como na literatura romântica inaugurada por Benjamin Constant, de qualquer investigação profunda dos supostos "movimentos do coração". Mas é nesses dois breves relances que algo passa. Mesmo que vazio e solidão, na superfície lisa da imagem. Estamos diante de novos protocolos narrativos, aptos a deixarem passar algo do sentir, ainda que não mais referido aos tortuosos meandros da alma moderna. Nesses protocolos, a estética do descuido e o olhar oblíquo são maneiras de expressar algo, mesmo que tosco, na canção repetida de modo banal, nem um pouco enfático. Entre o "olhar de dentro para fora" e o "de fora para dentro" machadianos, parece interpor-se, atualmente, o jogo infinito de imagens estilhaçadas, sem avesso ou espessura.

Ainda assim, algo da antiga alma - extenuada, esvaziada, talvez desdramatizadamente perplexa - também vaza na dissimulação e no olhar oblíquo de novas Capitus cibernéticas waMmecos

\section{NOTAS}

" Trabalho apresentado ao GT Comunicação e Sociabilidade, do XVIII Encontro da Compós, na PUCMG, Belo Horizonte, MG, em junho de 2009.

1 Trata-se do livro O encontro marcado, publicado em 1956. No livro são narrados os conflitos e as experiências do personagem Eduardo Marciano, à procura de si mesmo e da verdadeira razão de sua vida.

2 Trata-se do trabalho Videografias de si: registros do novo Ethos da contemporanidade, de Bruno César Simões Costa, da PUC-Minas.

\section{REFERÊNCIAS}

ASSIS, Machado de. "O espelho". In Obra completa, volume II. Rio de Janeiro: Aguilar, 1974.

BEZERRA, Benilton. "O ocaso da interioridade e suas repercussões sobre a clínica". In PLASTINO (org.). Transgressões. Rio: Contra Capa/Rios Ambiciosos, 2002.
CONSTANT, Benjamin. Adolphe. Paris: Les livres de poche, 1988.

DEBORD, Guy. La société du spectacle. Paris: Gallimard, 1992.

FREIRE COSTA, Jurandir. O vestígio e a aura: corpo e consumismo na moral do espetáculo. Rio de Janeiro: Garamond, 2005.

FOUCAULT, Michel. Histoire de la sexualité 1 (la volonté de savoir). Paris: Gallimard, 1976.

IZQUIERDO, Iván. Memória. Porto Alegre: Artmed Ed., 2002.

LAFAYETTE, Madame de. La princesse de Clèves. Paris: Folio, 2005.

MONTARDO, Sandra P. e PASSERINO, Liliana Maria. Espelhos quebrados no ciberespaço. Compós 2008. http:/ /www.compos.org.br/data/biblioteca_413.pdf

NIETZSCHE, Friedrich. Crepúsculo dos ídolos (ou como filosofar com o martelo). Rio de Janeiro: Relume Dumará, 2000.

Sämtliche Werke (KSA, 15 vol.). Berlim/Nova York:DTV/de Gruyter, 1988.

RABINOW, Paul. Antropologia da razão. Rio de Janeiro: Relume Dumará, 1999.

ROSE, Nikolas. The politics of life itself: biomedicine, power, and subjectivity in the twenty-first century. Princeton e Oxford: Princeton University Press, 2007.

SABINO, Fernando. O encontro marcado. Rio de Janeiro: Civilização Brasileira, 1956.

SENNETT, Richard. O declínio do homem público: as tiranias da intimidade. São Paulo: Companhia das Letras, 1998.

SIMÕES COSTA, Bruno César. Videografias de si: registros do novo Ethos da contemporanidade. Compós 2008. http://www.compos.org.br/data /biblioteca_412.pdf 